\title{
VERTICAL PRICE TRANSMISSION ALONG THE POTATO SUPPLY CHAIN IN LITHUANIA
}

\author{
Nelè Jurkẻnaité ${ }^{1}$, Dimitrios Paparas ${ }^{2}$ \\ ${ }^{1}$ Lithuanian Institute of Agrarian Economics, Lithuania \\ ${ }^{2}$ Harper Adams University, United Kingdom \\ nele@laei.lt
}

\begin{abstract}
Potato sector is one of the competitive areas of the European Union (EU) agriculture. Although Eurostat declared that in 2015 Lithuanian share in the EU-28 harvested production was modest and composed only $0.7 \%$, according to Food and Agriculture Organization of the United Nations (FAOSTAT), this crop remained on the list of top 10 commodities by net production value in Lithuanian agriculture. However, over the past decades the Lithuanian potato sector survived undesired transformations. The aim of this paper is to analyse the changes of the main indicators, related to the potato sector, and vertical price transmission among the chain of potatoes in Lithuania. The conducted research indicates the most important development trends of the potato sector and applies econometric techniques to investigate if there is any long-run relationship between the farm and retail prices of potatoes for the period of 2010 to 2016. Although the statistics show the shrinking production and domestic consumption of potatoes in Lithuania, the analysis of the vertical price transmission does not provide evidence of market inefficiencies. The Johansen cointegration test confirms the existence of a long-run relationship between the farm and retail prices, while the Granger causality test shows that there is a bidirectional causality between the examined series. The M-TAR model does not provide evidence of the farm and retail price asymmetry in the long run.
\end{abstract}

Key words: agriculture, supply chain, cointegration, potato, price transmission.

\section{Introduction}

Over the past decades, global markets of agricultural commodities survived several crises, accompanied by significant food price shocks peaked in 2008 and 2010 - 2011 (Islam, 2011). Previous dynamic changes of prices often resulted in market inefficiencies and led to the undesired impact on the welfare of farmers and consumers, and determined the changes in the crop structure in the EU member states. The aforementioned situation encouraged scientists to focus on the research explaining vertical price transmission mechanisms of agricultural and food products.

During the previous decades research on price transmission of fruit and vegetable markets was fragmentary and often led to the contradictory findings, which were mostly based on the case studies of selected agricultural markets in different countries. One of the most cited contributions to this research area investigating price transmissions of seventeen fresh vegetables (including potatoes) belongs to Ward (1982). The findings confirmed the relevance of asymmetry for the USA markets of fresh vegetables and allowed to identify a wholesale market as an actor with the major pricing power, while changes of retail and shipping prices lagged. Ward (1982) made an assumption that perishability could be a major determinant of price asymmetry among the supply chain of fresh vegetables and initiated the scientific discourse on vertical price transmission based on different estimation techniques.

Important contributions to this discourse were made by the studies of selected agricultural commodities in the USA (Brooker et al., 1997;
Girapunthong, VanSickle, \& Renwick, 2003; Acharya, Kinnucan, \& Caudill, 2011; Li \& Sexon, 2013), Brazil (Aguiar \& Santana, 2002), France (Hassan \& Simoni, 2002), Hungary (Bakucs, Fertő, \& Szabó, 2007), Greece (Rezitis \& Pachis, 2013), Slovakia (Pokrivcak \& Rajcaniova, 2014; Rajcaniova \& Pokrivcak, 2013), Dutch (Assefa, Kuiper, \& Meuwissen, 2014; Verreth et al., 2015), the United Kingdom, Germany, Denmark, the Netherlands and Spain (London Economics, 2004), Turkey (Aysoy, Kirli, \& Tumen, 2015), Malaysia (Zainalabidin \& Iliyasu, 2017). An essential conclusion emerges from the aforementioned research with conflicting results - every study brings valuable knowledge about supply chain management and critical market efficiency factors in the particular country. Generalizations and applications of research results to other industries and time periods often fail to explain the situation in the supply chain of the particular agricultural commodity (Aguiar \& Santana, 2002).

The paper contributes to this scientific discourse exploring vertical price transmission along the supply chain of potatoes. Despite the importance of this crop in the EU, only few researchers carried out a more comprehensive research on the situation of the vertical price transmission along the supply chain in Hungary (Bakucs, Fertő \& Szabó, 2007), Slovakia (Rajcaniova \& Pokrivcak, 2013; Pokrivcak \& Rajcaniova, 2014), Dutch (Assefa, Kuiper, \& Meuwissen, 2014; London Economics, 2004), the United Kingdom, Denmark, Germany and Spain (London Economics, 2004). Rajcaniova \& Pokrivcak (2013), Pokrivcak \& Rajcaniova (2014) found strong evidence of asymmetry in the vertical price transmission of 
Slovakian potato chain. In both research cases consumer prices reacted to the decrease in producer prices more rapidly than to the growth of price and were determined at the producer level. Assefa, Kuiper $\&$ Meuwissen (2014) studied the Dutch ware potato sector and the linkage of retailer oligopsony power with asymmetric behaviour. They found that price decreases on farms were transmitted partially while the increases almost fully and concluded that farmers' oligopoly power did not improve price transmission and could worsen the market situation.

Bakucs, Fałkowski \& Fertő (2007) investigated the transmission of producer and retail prices in Hungary and did not confirm findings about the price transmission asymmetry in the potato chain. The Hungarian potato sector was affected by seasonality and the price level determination came from the producer to retail. However, the long-run and shortrun vertical price transmissions were symmetric. The results of the Hungarian case corresponded to the previous findings of London Economics (2004) final report for Department for Environment, Food and Rural Affairs (DEFRA) covering research of the potato sector in six EU member states and reporting about symmetric farm-retail price transmissions. Peculiarities of national potato markets were noticed: the United Kingdom, Denmark and Spain markets had a long-run symmetric transmission, Germany had a short-run, the Netherlands potato sector had a longrun symmetric transmission for the producer-retail direction and a short-run symmetric transmission for the retail-producer direction. The speed of price adjustments in the selected countries differed; however, the proportion of the adjustment was higher for the producer price changes than for the retail (except in the Denmark case).

The aim of this paper is to analyse the changes of the main indicators related to the potato sector and vertical price transmission among the chain of potatoes in Lithuania. Though some researchers reported on the structural transformations of the potato sector in Lithuania during the recent decades (Lukošiute, 2009;
Melnikienè, 2017), the research on vertical price transmission of the EU countries omitted Lithuanian case as the reliable statistics was not available. The paper covers this gap and provides empirical evidence on the price transmission among the chain of potatoes, contributing to a better understanding of the potato sector development trends and market functioning issues. The conducted research provides a comprehensive view on the situation of vertical price transmission along the potato chain utilising different techniques to show multiple aspects of market inefficiency for the same period.

\section{Materials and Methods}

The paper covers two objectives, which are implemented applying different methodological approaches: 1) to analyse the main indicators of the potato sector's development, 2) to study vertical price transmission along the chain of potatoes in Lithuania.

The first objective - the analysis of the main indicators of the potato sector's development employs methods of graphical and comparative data analysis. This task investigates changes for the period from 2010 to 2016 and relies on the secondary data from Statistics Lithuania. The results identify main development trends related to potato production, domestic consumption, and self-sufficiency.

The second objective - the study of vertical price transmission along the chain of potatoes in Lithuania also covers the period from 2010 to 2016 and analyses the relationships between the average selling prices on commercial farms and the average retail prices for fresh potatoes of Lithuanian origin. The research of vertical price transmission of the potato sector relies on a weekly data collected by the state enterprise 'Agricultural Information and Rural Business Centre'. The price on farm is set as the average of minimum and maximum price; the retail price shows the average price in the main network supermarkets of 7 counties. Figure 1 illustrates changes of the aforementioned average farm and retail prices. The second objective employs different econometric techniques applied

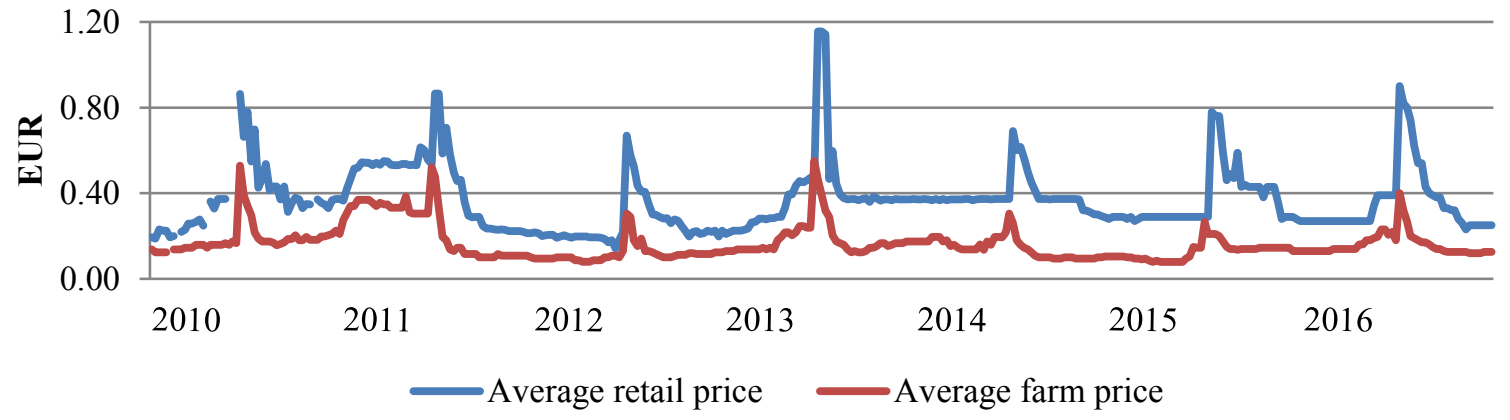

Source: SE ‘Agricultural Information and Rural Business Centre’ and authors' calculations.

Figure 1. Average potato prices: farm and retail levels. 
for the analysis of time series compiling a 4-stage methodological research framework in order to explain the relationships between the farm and retail prices of potatoes. The econometric tests were run employing Eviews software.

The methodological 4-stage research framework for the investigation of the vertical price transmission is based on the analysis of the aforementioned literature on research of vertical price transmission in fruit and vegetable markets. The structure of the framework is set as follows: 1) ADF test; 2) Johansen cointegration test; 3) Granger causality test; 4) M-TAR model.

Stage 1: the augmented Dickey-Fuller (ADF) test (Dickey \& Fuller, 1979). The non-stationary data can lead to a 'spurious regression' (Brooks, 2008). In this case, the empirical results of the research could be in accordance with the theory and the hypothesis, but the regression, indicating the relationship between prices, has no meaning. The series of the farm and retail prices are tested for the unit root employing the ADF test. If the null hypothesis $\left(\mathrm{H}_{0}\right)$ is not rejected, it is presumed that the analysed sample of price series contains a unit root. The alternative hypothesis is in favour of stationary price series without a unit root. The results of the ADF test make an impact on the selection of the further econometric analysis techniques. The proposed methodological research framework is applied only if the $\mathrm{H}_{0}$ is rejected.

Stage 2: the Johansen cointegration test (Johansen, 1991; 1995). Cointegration analysis is an empirical technique used to establish the degree to which variables are related in the long run. The introduction of cointegration was due to the realisation that most of the financial data is non-stationary. Curtbertson (1996) implied that regression models from non-stationary time series variables cause spurious regressions. However, when cointegration deals with data with stochastic trends, the problem of spurious regression is avoided.

Johansen developed a methodology for the analysis of the cointegration between the selected variables and common trends in vector autoregression (VAR) models with Gaussian errors and seasonal dummies (Johansen, 1991). This test is used to identify the existence of the long-run relationship between the farm and retail prices. It allows testing more than one cointegration relationships and includes two types of tests: trace and eigenvalue. The Johansen trace test examines the $\mathrm{H}_{0}$ that the number of linear combinations $r$ is equal to a given value, while the alternative hypothesis is in favour that the number of linear combinations $r$ is greater than a given value. The rejection of the $\mathrm{H}_{0}$ means that there is a longrun relationship between the farm and retail prices. Maximum eigenvalue allows testing for the existence of more than one combination $(r+1)$ of the price variables. The rejection of the $\mathrm{H}_{0}$ allows stating that the certain number of possible linear combinations exists.

Stage 3: the Granger causality test (Granger, 1969). Granger causality tests for the short-run relationship between the farm and retail prices. This stage assists in defining empirically the direction of causality between the farm and retail prices, and exploring the feedback situation. The Granger causality test studies whether the farm price causes the retail price and how much of the current selected price variable could be explained by its values in the past and by values of the second price variable. Granger causality exists if one price helps to predict another or if the coefficients on the lagged second price variable are statistically significant. Test runs two-way causation investigating if the farm price causes the retail price, and vice versa. However, the Granger causality test does not assure that one price is causing another; the results only confirm that the price series of one variable helped to predict another.

Stage 4: the momentum threshold autoregressive (M-TAR) model (Enders \& Granger, 1998; Enders \& Silkos, 2001). The M-TAR model for unit roots extends standard cointegration analysis and allows investigating nonlinear adjustment mechanisms and identifying asymmetry. The asymmetry could demonstrate that time series is 'more 'momentum' in one direction than the other (Enders \& Silkos, 2001), i. e. positive and negative price shocks in the long run are transmitted with different intensity. The two-step procedure is followed. The first step tests the $\mathrm{H}_{0}$ that there is no cointegration between prices in the longrun relationship. The second step tests the $\mathrm{H}_{0}$ that there is a symmetric adjustment mechanism between the farm and retail prices in the long-run equilibrium.

\section{Results and Discussion}

Main indicators of potato sector development in Lithuania

The potato sector, especially potatoes for human consumption, is one of the competitive areas of the EU agriculture. Though in 2015 Lithuanian share in the EU-28 harvested production was modest and composed only $0.7 \%$ (De Cicco \& Jeanty, 2017), this crop remained on the list of top 10 commodities by net production value in Lithuanian agriculture(FAOSTAT.., 2017). In 2016 this specialization remained unpopular at agricultural companies and enterprises, and 97.3\% of Lithuanian potatoes were harvested at farmer and family farms (Melnikienè, 2017).

The comparison of the most important indicators of potato sector identifies undesired development trends (Table 1). The harvested area fell by $39.6 \%$ from 2010 to 2016. During the same period, the harvest of potatoes decreased from 476.6 to 351.5 thousand 
Main indicators of the potato sector in Lithuania

\begin{tabular}{|l|c|c|c|c|c|c|c|c|}
\hline & 2010 & 2011 & 2012 & 2013 & 2014 & 2015 & 2016 & $\begin{array}{c}2016 \text { compared } \\
\text { with 2010 } \\
(2010=100 \%)\end{array}$ \\
\hline Harvest, thou t & 476.9 & 587.7 & 549.9 & 426.5 & 468.5 & 399.2 & 351.5 & 73.7 \\
\hline Average yield, $100 \mathrm{~kg} \mathrm{ha}^{-1}$ & 130.0 & 156.0 & 171.0 & 148.0 & 172.0 & 170.0 & 159.0 & 122.3 \\
\hline Harvested area, thou ha & 36.6 & 37.7 & 32.2 & 28.7 & 27.3 & 23.5 & 22.1 & 60.4 \\
\hline Production per capita, kg & 154.0 & 194.0 & 184.0 & 144.0 & 160.0 & 137.0 & 123.0 & 79.9 \\
\hline Consumption per capita, kg & 94.0 & 99.0 & 95.0 & 93.0 & 96.0 & 94.0 & 94.0 & 100.0 \\
\hline Self-sufficiency, \% & 79.0 & 107.0 & 103.0 & 88.0 & 100.0 & 90.0 & 84.0 & 106.3 \\
\hline Domestic consumption, thou t & 607.5 & 547.2 & 532.6 & 485.2 & 470.6 & 442.9 & 416.7 & 68.6 \\
\hline
\end{tabular}

Source: Lietuvos..., 2015; Lietuvos..., 2017; authors' calculations.

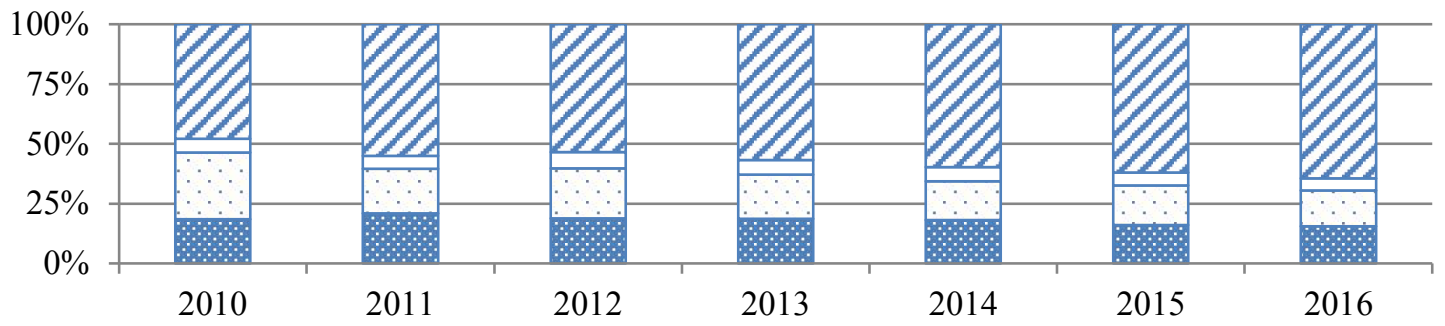

․․ For seed $\square$ For fodder $\square$ Losses $\square$ Human consumption

Source: Lietuvos..., 2015; Lietuvos..., 2017.

Figure 2. Structure of potato total domestic consumption.

tons. The average yield increased, but the results showed significant fluctuations and varied from 130.0 to $172.0 \mathrm{~kg} \mathrm{ha}^{-1}$. The indicator of potatoes per capita fell by $20.1 \%$. However, consumption per capita remained almost stable since 2010 with a moderate increase from 2011 to 2014. Despite the decline in the production observed in $2010-2016$, the indicator of self-sufficiency improved. The annual indicator of self-sufficiency demonstrated significant fluctuations: in 2011, 2012 and 2014 the figure exceeded $100.0 \%$, but since 2015 the dependence on imported potatoes increased. Import of potatoes is mostly orientated for the periods of early harvests in countries with warmer weather.

Domestic consumption of potatoes fell by $31.4 \%$ from 2010 to 2016. The annual decrease of this indicator was accompanied by the transformation of domestic consumption structure (Figure 2). Over the analysed period, the domestic consumption of potatoes for agricultural purpose fell (seed had a drop of $15.7 \%$, fodder $-46.2 \%$ ), but the share of human consumption in the structure increased by $34.4 \%$.

The consumption of processed potatoes is increasing, while the consumption of fresh potatoes demonstrates a decrease trend. Melnikienè (2017) argues that the indicator of human consumption for Lithuania is higher than the EU average and the further decrease of the consumption is possible in the immediate future. The unfavourable demand trends affect the supply of potatoes and the structure of agricultural crops gradually transforms.

The vertical price transmission among the potato chain

The shrinking of the potato sector in Lithuania could be influenced by the inefficiency of vertical supply chain. The paper investigates the relationships between the farm and retail prices applying the 4-stage research framework for the identification of different chain inefficiency aspects.

The first step of the empirical analysis is the ADF test, which examines the stationarity of the farm and retail price series. Table 2 presents the results of the ADF test on the examined series and the results show that for both prices the $t$-statistic is greater than the critical value at $5 \%$ level of significance when prices are expressed in levels. This is also supported by the $p$-value of probability which is less than 0.05 . Thus, the series of the farm and retail prices does not have a unit root, the $\mathrm{H}_{0}$ is rejected and the examined series can be characterized as stationary and integrated of order zero. 
Table 2

Results of the ADF unit root test for the farm and retail prices

\begin{tabular}{|l|c|c|c|}
\hline \multicolumn{1}{|c|}{ Variables } & $t$-statistic & $p$-value & Critical value (5\%) \\
\hline Farm price $(0 *)$ & -3.51 & 0.01 & -2.86 \\
\hline Retail price $(0)$ & -4.42 & 0.00 & -2.86 \\
\hline
\end{tabular}

Note: * Parentheses in the ADF test indicate the lag length based on Schwarz information criterion.

The Johansen cointegration test results for the farm and retail prices

\begin{tabular}{|l|c|c|c|c|c|c|c|}
\hline \multirow{2}{*}{$\begin{array}{c}\text { Hypothesized } \\
\text { No. of CE(s) }\end{array}$} & \multicolumn{3}{|c|}{$\begin{array}{c}\text { Unrestricted cointegration rank test } \\
\text { (Trace) }\end{array}$} & \multicolumn{3}{|c|}{$\begin{array}{c}\text { Unrestricted cointegration rank test } \\
\text { (Maximum Eigenvalue) }\end{array}$} & Prob.** \\
\cline { 2 - 8 } & Eigenvalue & $\begin{array}{c}\text { Trace } \\
\text { statistic }\end{array}$ & $\begin{array}{c}\text { Critical Value } \\
(5 \%)\end{array}$ & Eigenvalue & $\begin{array}{c}\text { Max-Eigen } \\
\text { statistic }\end{array}$ & $\begin{array}{c}\text { Critical Value } \\
(5 \%)\end{array}$ & \\
\hline $\mathrm{r}=0^{*}$ & 0.12 & $43.20^{*}$ & 12.32 & 0.12 & $42.62^{*}$ & 11.22 & 0.00 \\
\hline $\mathrm{r}=1$ & 0.00 & 0.58 & 4.13 & 0.00 & 0.58 & 4.13 & 0.51 \\
\hline
\end{tabular}

Note: * indicate rejection of the $\mathrm{H}_{0}$ at the $5 \%$ level of significance. ${ }^{* *}$ MacKinnon-Haug-Michelis (1999) $p$-values.

The second step is the Johansen cointegration test. This approach uses the maximum likelihood estimation in a VAR model. There are two statistics reported using this test: the trace and maximum eigenvalue. We found evidence from the ADF test that all the series are integrated of order zero. The results of the Johansen approach indicate that there is one cointegration vector between the tested price series (Table 3). The $p$-value 0.00 is lower than 0.05 . The comparison of trace statistic and maximum eigenvalue statistic to critical values allows rejecting $\mathrm{H}_{0}(r=0)$ at the $5 \%$ significance level. The Johansen cointegration test demonstrates a long-run relationship between the farm and retail prices of the potato chain.

The Granger causality test is the third step in order to ensure that residuals are uncorrelated. The second step shows that there is one cointegration vector for the examined price series, so the Granger causality test can be defined as a joint test ( $F$-tests) for the significance of the lagged value of the assumed exogenous variable

Table 4

The Granger causality test results for the farm and retail prices

\begin{tabular}{|l|c|c|}
\hline \multicolumn{1}{|c|}{$\mathrm{H}_{0}$} & $F$-statistic & Prob. \\
\hline Retail price does not Granger cause farm price & $6.74^{*}$ & 0.00 \\
\hline Farm price does not Granger cause retail price & $35.19^{*}$ & 0.00 \\
\hline
\end{tabular}

Note: * indicate rejection of the $\mathrm{H}_{0}$ at the $5 \%$ level of significance.

The threshold autoregressive model for farm and retail prices

\begin{tabular}{|l|c|c|}
\hline \multicolumn{1}{|c|}{ Variable } & Coefficient & Std. Error \\
\hline Above Threshold $(\rho 1)$ & -0.19 & 0.04 \\
\hline Below Threshold $(\rho 2)$ & -0.05 & 0.04 \\
\hline Threshold Value & 0.00 & \\
\hline$F$-equal $(\rho 1=\rho 2)$ & 5.25 & $(3.07)^{*}$ \\
\hline$T$-max value & -1.34 & $(-2.07)^{*}$ \\
\hline$F$-joint $($ Phi $)(\rho 1=\rho 2=0)$ & 9.24 & $(5.78)^{*}$ \\
\hline
\end{tabular}

Note: * simulated critical values for $5 \%$ significance level. 
and for the significance of the error correction term. The results are reported in Table 4 . The $p$-values are lower than 0.05 and the comparison of $F$-statistic to critical values indicates that there is a bidirectional causality between the farm and retail prices, and both variables cause each other simultaneously.

The fourth step tests for the asymmetry between the farm and retail prices. Threshold autoregressive models are used to determine whether asymmetry is present within the chain. The results for the farm and retail price threshold autoregressive models can be found in Table 5. The results suggest that there is a cointegration but the hypothesis of asymmetry is rejected, thus, positive and negative shocks from the retail prices affect the farm prices with the same magnitude.

To test for asymmetry, we separate the residuals obtained from the long-run equation into positive and negative with a zero threshold. The positive residuals (above threshold) are named as $\rho 1$ and the negative (below threshold) $-\rho 2$. The $\rho 1=\rho 2=0$ represents the result for cointegration under asymmetry. In Table 5 it is named as $F$-joint (Phi) and amounts to 9.24. The $\mathrm{H}_{0}$ means that there is no cointegration and the alternative hypothesis states that there is a cointegration. The comparison of $F$-joint (Phi) with the critical value $F$-stat $(9.24>6.07)$, provided in Enders \& Siklos (1998), allows to reject $\mathrm{H}_{0}$. The alternative hypothesis means that there is a cointegration under asymmetry.

The $\rho 1=\rho 2$ represents the result for asymmetry. In the Table 5 it is named as $F$-equal. The $\mathrm{H}_{0}$ presumes symmetry and the alternative hypothesis is in favour of asymmetry. The comparison of the $F$-equal with the critical value $F$-stat $(5.25<6.07)$ does not allow to reject the $\mathrm{H}_{0}$ and they witness in favour of symmetry.

The results of the Lithuanian case correspond to Bakucs, Fałkowski \& Ferto" (2007) findings for the Hungarian potato chain. The long run symmetric farmretail transmission was also found in some countries included into London Economics (2004) final report for DEFRA. The Lithuanian case of the potato chain does not witness serious issues of market inefficiency as both farmers and retailers influence market prices.

\section{Conclusions}

Analysis of the main indicators for the period 2010 - 2016 shows the shrinking of the Lithuanian potato sector. The harvested area fell by $39.6 \%$, the harvest reduced by $26.3 \%$ (though the average yield increased by $22.3 \%$ ). The situation in the potato sector is determined by changes in the structure of domestic consumption, e. g. declining use of agricultural commodity for agricultural and human consumption.

The econometric analysis of vertical price transmission among the chain of potatoes does not indicate serious problems which could result in market inefficiencies. The Johansen cointegration test confirms that there is a long-run relationship between the farm and retail prices. The Granger causality test shows the evidence of two-way causality and confirms that in the short-run the changes of prices are influenced by both the producer and the retailer. The M-TAR modelling allows stating that in the long run increases and decreases of prices are transmitted with similar intensity and shocks are fully transmitted between the farmer and retailer.

The conducted research allows to make an assumption that the shrinking of potato sector could be better explained by changes in the consumption than by market inefficiency issues. Though the results of the empirical research do not show obvious evidence of market inefficiency, the conclusions can be influenced by research limitations determined by available statistics. The current research draws attention to the farm and retail prices, however, some researchers provide an evidence of market inefficiencies between different stakeholders along the chain, while the empirical research on the farm and retail prices does not show serious problems. The further research could investigate the price transmission situation within a chain with more stakeholders.

\section{References}

1. Acharya, R.N., Kinnucan, H.W., \& Caudill, S.B. (2011). Asymmetric Farm-retail Price Transmission and Market Power: ANew Test. Applied Economics, 43(30), 4759-4768. DOI: 10.1080/00036846.2010.498355.

2. Aquiar, D.R.D., \& Santana, J.A. (2002). Asymmetry in Farm to Retail Price Transmission: Evidence from Brazil. Agribusiness 18(1), 37-48. DOI: 10.1002/agr.10001.

3. Assefa, T.T., Kuiper, W.E., \& Meuwissen, M.P.M. (2014). The Effect of Farmer Market Power on the Degree of Farm Retail Price Transmission: A Simulation Model with an Application to the Dutch Ware Potato Supply Chain. Agribusiness, 30(4), 424-437. DOI: 10.1002/agr.21371.

4. Aysoy, C., Kirli, D.H., \& Tumen, S. (2015). How does a shorter supply chain affect pricing of fresh food? Evidence from a natural experiment, Food Policy, 57(November): 104-113. DOI: 10.1016/j. foodpol.2015.10.003.

5. Bakucs, L.Z., Fertő, I., \& Szabó, G.G. (2007). Price transmission in the Hungarian vegetable sector. Studies in Agricultural Economics, 106, 23-40. 
6. Brooker, J.R., Eastwood, D.B., Carver, B.T., \& Gray, M.D. (1997). Fresh Vegetable Price Linkage Between Grower/Shippers, Wholesalers, and Retailers. Journal of Food Distribution Research, 28: 54-61.

7. Brooks, C. (2008). Introductory Econometrics for Finance ( $2^{\text {nd }}$ ed.). New York, USA: Cambridge University Press.

8. Curtbertson, K. (1996). Quantitative Financial Economics: Stocks, Bonds, and Foreign Exchange. New York, USA: John Wiley and Sons Ltd.

9. De Cicco, A., \& Jeanty, J.C. (2017). The EU potato sector - statistics on production, prices and trade. Retrieved November 10, 2017, from: http://ec.europa.eu/eurostat/statistics-explained/index.php/The_EU_ potato_sector_-_statistics_on_production,_prices_and_trade.

10. Dickey, D.A., \& Fuller, W.A. (1979). Distribution of the Estimators for Autoregressive Time Series with a Unit Root. Journal of the American Statistical Association, 74(366): 427-431. DOI: 10.2307/2286348.

11. Enders, W., \& Siklos, P.L. (2001). Cointegration and Threshold Adjustment. Journal of Business \& Economic Statistics, 19(2), 166-176. DOI: 10.1198/073500101316970395.

12. Enders, W., \& Granger, C.W.J. (1998). Unit-Root Tests and Asymmetric Adjustment with an Example Using the Term Structure of Interest Rates. Journal of Business \& Economic Statistics, 16(3), 304-311. DOI: $10.2307 / 1392506$.

13. FAOSTAT. Commodities by country. (2017). Retrieved November 10, 2017, from: http://www.fao.org/ faostat/en/\#rankings/commodities_by_country.

14. Granger, C.W.J. (1969). Investigating Causal Relations by Econometric Models and Cross-spectral Methods. Econometrica, 37(3), 424-438.

15. Girapunthong, N., VanSickle, J.J., \& Renwick, A. (2003). Price Asymmetry in the United States Fresh Tomato Market. Journal of Food Distribution Research, 34(3), 51-59.

16. Hassan, D., \& Simioni, M. (2002). Price Linkage and Transmission between Shippers and Retailers in the French Fresh Vegetable Channel, No 24794, In Xth EAAE Congress 'Exploring Diversity in the European Agri-Food System', 28-31 August 2002 (pp. 1-17). Spain: EAAE.

17. Islam, R. (2011). Rising Food and Energy Prices in Europe and Central Asia. Washington, DC, USA: World Bank.

18. Johansen, S. (1991). Estimation and Hypothesis Testing of Cointegration Vectors in Gaussian Vector Autoregressive Models. Econometrica, 59(6), 1551-1580. DOI: 10.2307/2938278.

19. Johansen, S. (1995). Likelihood-Based Inference in Cointegrated Vector Autoregressive Models. New York: Oxford University Press Inc.

20. Li, C., \& Sexon, R.J. (2013). Grocery-Retailer Pricing Behavior with Implications for Farmer Welfare. Journal of Agricultural and Resource Economics, 38(2): 141-158. Retrieved December 20, 2017, from: http://www.jstor.org/stable/23496747.

21. Lietuvos žemès ūkis 2016 (Agriculture in Lithuania 2016). (2017). Vilnius: Lietuvos statistikos departamentas (in Lithuanian).

22. Lietuvos žemès ükis 2014 (Agriculture in Lithuania 2014). (2015). Vilnius: Lietuvos statistikos departamentas (in Lithuanian).

23. Lukošiute, I. (2009). Lietuvos bulvių sektoriaus konkurencingumas (The competitiveness of Lithuanian potato sector in the European Union market). Management theory and studies for rural business and infrastructure development, 16(1), 74-81 (in Lithuanian).

24. London Economics. (2004). Investigation of the determinants of farm-retail price spreads: final report to DEFRA. Retrieved December 5, 2017, from: https://londoneconomics.co.uk/wp-content/ uploads/2011/09/92-Investigation-of-the-determinants-of-farm-retail-price-spreads.pdf.

25. Melnikienè, R. (2017). Lietuvos žemès ir maisto ūkis 2016 (Agriculture and Food sector in Lithuania 2016). Vilnius: Lietuvos agrarinės ekonomikos institutas (in Lithuanian).

26. Pokrivcak, J., \& Rajcaniova, M. (2014). Price Transmission along the Food Supply Chain in Slovakia. Post-Communist Economies, 26(4), 555-568. DOI: 10.1080/14631377.2014.937111.

27. Rajcaniova, M., \& Pokrivcak, J. (2013). Asymmetry in Price Transmission Mechanism: the Case of Slovak Potato Market. Review of Agricultural and Applied Economics, XVI(2), 16-23.

28. Rezitis, A.N., \& Pachis, D.N. (2013). Investigating the Price Transmission Mechanism of the Greek Fresh Tomato Market with a Markov Switching Vector Error Correction Model. Agricultural Economics Review, $14(2), 29-45$.

29. Verreth, D.M.I., Emvalomatis, G., Bunte, F., Kemp, R., \& Oude Lansink, A.G.J.M. (2015). Price Transmission, International Trade, and Asymmetric Relationships in the Dutch Agri-Food Chain. Agribusiness, 31(4), 521-542. DOI: 10.1002/agr.21420. 
30. Ward, R.W. (1982). Asymmetry in Retail, Wholesale, and Shipping Point Pricing for Fresh Vegetables. American Journal of Agricultural Economics, May, 205-212.

31. Zainalabidin, M., \& Iliyasu, A. (2017). Analysis of Asymmetric Price Transmission of Selected Vegetables in Peninsular Malaysia. Malaysian Journal of Mathematical Sciences, 11(S) February, 87-100. 